\title{
Corrective Feedback to Improve Students' Writing Ability
}

\author{
Lina Mariana $^{1} \&$ Diani Nurhajati ${ }^{2}$ \\ ${ }^{1,2}$ Universitas Nusantara PGRI Kediri \\ E-mail: 'linamariana1009@yahoo.co.id, ${ }^{2}$ dianihamzah@yahoo.com
}

Received: 23 October 2017; Revised: 1 November 2017; Accepted: 1 November 2017

\begin{abstract}
Abstrack
This article refers to a Lesson Study research implementing Corrective Feedback to enhance the students' writing ability. The research aims to identify: (1) kinds and types of corrective feedback given by the lecturer to improve the students' writing ability and (2) the process of giving corrective feedback in Creative Writing classroom. It was conducted to 37 second year students in the odd semester of 2016/2017 academic year of a University of Nusantara PGRI in Kediri, East Java. Questionaire, interview and tests were given before and after the implementation of corrective feedback activities and it had two cycles, consisting of three main stages, they are Plan, Do and See stage. The instruments used were questionnaire and interviews were given to the students before and after the implementation. The result showed that corrective feedback activities improved students' writing ability. The students were interested in creative writing class as they paid good attention and felt fun when they were involved in making creative paragraphs consisting of a short story to be presented in front of the class and expressed their ideas upon the stories given. Their worries of making mistakes were decreased since the lecturer gave oral corrective feedback directly when they made mistakes in deciding the intrinsic elements of making short story and also when the lecturer made some notes upon their works as written corrective feedback discussing about the aspects of writing such as grammatical structure of sentences, vocabulary, ideas, organization and also mechanic. After having some beneficial notes to be revised the students will absolutely get the points about what the mistakes and weaknesses they made that not to be done again for the next project. .
\end{abstract}

Key words: society; Islam; java; paranormal;

\section{Introduction}

Writing is important because not only reinforces grammatical structures, idioms and vocabulary but also the students have a chance to be adventurous with the language and finally the students are very involved with the new language. In this part, the students have a unique way to reinforce learning by combining constant use of eye, hand and brain.

There are some difficulties related to writing. The psychological difficulty in which the writer has to decide what information the read- ers need. Furthermore, there is a linguistic difficulty in that language used in written language that is different from that used in speech and in addition, there is a cognitive difficulty in which the students have to organize their obliged to write and they do not know what to write more on their paper.

Preliminary research which include observation, text, questionaire, and interview showed that the from the most difficulty for students in writing was on developing ideas in paragraph. This was indicatedfrom some 
following problems: a) Since the researcher thinks that the most important problem faced by the students that needs a solution as soon as possible is how the students are able to produce a good creative writing, the research is decided to conduct in odd semester.

The challenges faced by the whole students of English Department in writing class whether it is creative writing class or scientific writing class, they feel under pressure when they realize that they are weak in grammatical structure, mechanic, vocabulary and ideas as well. Getting ideas fastly and accurately, developing it well and also manage it into good and smooth paragraph is a kind of extreme difficulties they have. The objectives of conducting this research are: 1) finding out the types and kinds of corrective feedback given by the lecturer to the students at enhancing th eir ability, 2) describing the process of teaching students using corrective feedback through lesson study in university of nusantara pgri kediri.

\section{Material and Methods}

The research method used by the team since it is collaborative research means that conducting this kind of research needs the model and her collaborators work together started from Plan stage until see stage.

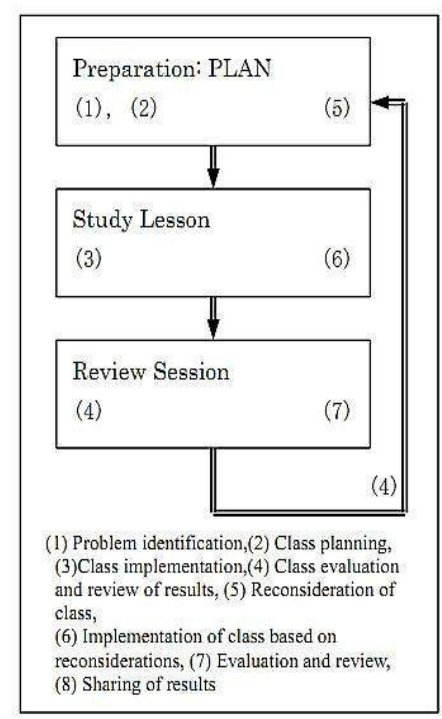

The simple diagram above explains about the way how this research was conducted following the right procedure. The ways how the cycle was conducted during teaching learning process will absolutely teach the next researcher to conduct a similar research.

\section{Results and Discussion}

The research result here will discuss fristly about the types or kinds of Corrective Feedback given by the lecturer to the students. The first is Oral Corrective Feedback that was given to the students directly after the students presenting the result of their discussin about the topic that will be discussed in their project that is about presenting the intrinsic elements of making or composing short story as it is a part of creative writing whereas they have to be able to make to be creative in developing their ideas in presenting story that provides the readers with the moral value based on the types of their readers as it will be the students of elementary school students.

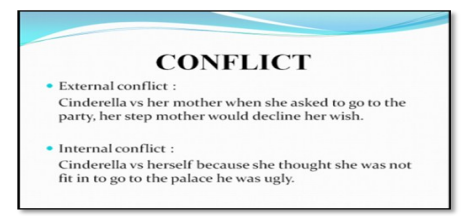

The above picture shows that in oral corrective feedback the material discussed is about the content of the story that they will compose after the end of teaching learning process. The achievement they have to reach is making a short story to be read by the elementary school students.

While the written corrective feed as the second kind of corrective feedback done by the lecturer when the model had to read the students' product before submitting it. This is the example of making corrective feedback consisting of the an aspects of writing.

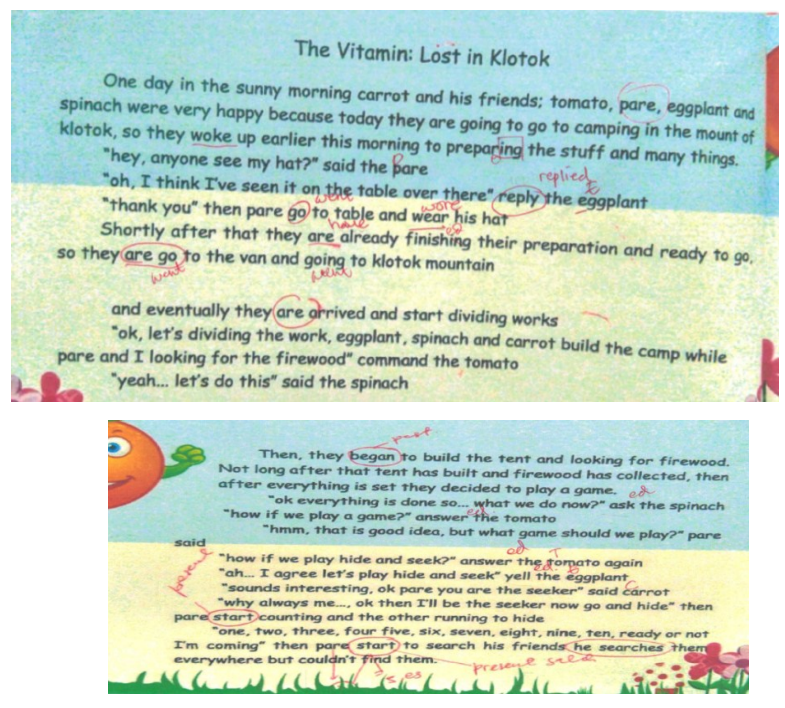


While the second research question about the process of teaching creative writing using corrective feedback is easily explained here.

\section{Plan stage}

In this stage; Plan Stage, the model or the lecturer of creative writing classroom worked hard with the team to prepare all instruments in taching learning process of creative writing classroom, such as: preparing the students' material to be discussed. After asking to the lecturer model about the students problems in writing during her experience in teaching the class, the team consisting the model, the collaborators and also the representative from the students, they decided to prepare the material carefully, then composing the students handout and worksheet as well. It is the best way for gathering the lecturer model of creative writing class and also the collaborators from another subject. Sometimes they faced the same problem in facing the students problem even though it was a different subject.

\section{Do Stage}

Here the model and the team implemented the teaching learning preparation in creative writing classroom. They have the different duties in it. In Do Stage, the lecturer model applied the preparation during teaching learning process followig the preparation or based on Lesson Plan thay they made before, that will be continued by giving the students task based on the worksheet that they have prepared before, after they learnt much about students' handout. While the collaborators will observe carefully all the whole things in the classroom as the fact shown.

The collaborators observed the students' responses while the lecturer taught them whether they understood the material or not. Next, the observer also abserved the ways how the lecturer or the model teaught the students, observing while the instructionwas given clearly or not. Sometimes, students' difficulties appeared from the unclear instruction from the lecturer.

\section{See Stage}

While in the last stage of implementing the procedure of Lesson Study, that is see stage. All the team consisting of the model and the collaborators observe the result of conducting the research by watching and paying close attention to the video recording. There all the eyes could watch whether th teaching learning process worked well or not. They sat together to get the real strengths of conducting this such kind of research about applying Lesson Study as a method of research. It is a kind of collaborative research, thus it has some similar characteristic with Classroom Action Research.

\section{Conclusion}

One best thing that the researcher may conclude form conducting the research is by using Lesson Study as a method of research, the lecturer was helped much by the collaborators, even composing the material, handout also worksheet will be examined firstly before applied in the classroom, means that it will be helpful for the students and also the researcher as well. Then Corrective feedback is extremely needed by the students to know better about the mistakes upon their works easily and by reading the note from the lecturer will be quitely helpfull for the students to remember their mistakes that will not be done for the next product that they have to make.

\section{Suggestion}

Based on the research result, it is the best suggestion for the lecturer of anykind writing to be creative in teaching the students by carefully choosing the method in teaching them. Not only asking the students to write about anything but also introducing them to another kinds of paragraph or writing. Not only writing the real fact of life but also they are introduced to the imaginative writing, since it will take the students heart and soul to be involved in their product besides teaching them to move their heart and soul also imagination to present something new.

\section{References}

Ary, D., Jacobs, L.C., Sorensen, C, \&Razavieh, A. (2010).Introduction to Research in Education Eight Edition. Wadsworth: Cengage Learning.

Baba, Takuya. (2007). How is Lesson Study Implemented?. In Isoda, Masami., Ste- 
phens, Max., Ohara, Yutaka., Miyakawa, Takeshi. (Eds.), JAPANESE LESSON STUDY IN MATHEMATICS - Its Impact, Diversity and Potential for Educational Improvement . (Online), available: http://www.asianscientist.com/ b o o k s / w p - c o n t e n t / uploads/2013/05/6339_chap01.pdf Downloaded on June 30, 2014

Bilyeu, Linda. (2009). Teachers and Librarians Collaborate in Lesson Study. Knowledge Quest Professional Practice. 38(2). http://www-tc.pbs.org/ teachers/librarymedia/aasl/bilyeu.pdf .

Brown, DH. (2000). Teaching by Principles An Interactive Approach to Language Pedagogy Second Edition. California: Longman Group Ltd.

Creswell, John W. (1994). Reasearch Design Qualitative \& Quantitative Approaches. New Delhi: Sage Publication.

Dudley, P. (2004). Lessons for learning: Research Lesson Study, innovation, transfer andmetapedagogy: a design experiment? Paper Presented at the 5th Annual Conference of the teaching and learning Research Program, Cardiff.

Haithcock, Frances. (2010). A Guide to Implementing Lesson Study for District and School Leadership Teams in Differentiated Accountability Schools: First Edition. Florida: Florida Department of Education Division of K-12 Public Schools Bureau of School Improvement.

Rock, Tracy C. and Wilson, Cathy. (2005). Improving Teaching through Lesson Study. Teacher Education Quarterly. 32(1). http://www.teqjournal.org/ Back\%20Issues/Volume\%2032/Vol\% $2032 \% 20 \mathrm{PDFS} / 32$ 1/rock\&wilson$32 \_1 . p d f$

Sugiyono. (2012). Metode Penelitian Pendidikan. Bandung: CV. Alfabeta. 